\title{
Overview of the Current State and Problems of Accommodation Facilities Development in the Regions of the Central Federal District of the Russian Federation
}

\author{
Galina V. Astratova ${ }^{1,2}$, Irina G. Pavlenko ${ }^{3,}$, Marina M. Kireeva ${ }^{4}$, Anna P. \\ Vostrova $^{4}$, Igor A. Bukreev ${ }^{5}$ \\ ${ }^{I}$ Ural Federal University named after the first President of Russia B. N. Yeltsin, Yekaterinburg, Russia \\ ${ }^{2}$ Ural Juridical Institute of MIA of Russia, Yekaterinburg, Russia \\ ${ }^{3}$ V.I. Vernadsky Crimean Federal University, Simferopol, Russia \\ ${ }^{4}$ Ivanovo Branch of the Federal State Budgetary Educational Institution of Higher Education "Plekhanov Russian \\ University of Economics", Ivanovo, Russia \\ ${ }^{5}$ Humanitarian and Pedagogical Academy (branch) of the Crimean Federal University named after V.I. Vernadsky, \\ Yalta, Russia \\ *Corresponding author.Email:11irin@rambler.ru
}

\begin{abstract}
The article presents the results of a study of the current state and problems of accommodation facilities development, i.e. objects of the tourist industry, including a building and its structures and parts, in which one or more equipped living rooms (premises) intended for accommodation and temporary residence of tourists are located on the example of a number of regions of the Central Federal District of the Russian Federation. For comparison, the following regions are selected: Ivanovo, Vladimir, Kostroma and Yaroslavl regions of the Central Federal District of Russia. The choice of research objects is determined by the following main factors: 1) location (close location to the capital of the Russian Federation Moscow), 2) belonging to the famous tourist route "Golden Ring of Russia"; 3) the presence of similar historical, natural and cultural conditions for the development of tourism and the hospitality industry in this region. The purpose of the study was to analyze and summarize information about the regional markets of hotel services. The relevance of the study of accommodation facilities in the processes of tourism development in the conditions of its recovery after the COVID-19 pandemic is substantiated. The study was carried out on the basis of generalization of official statistical data of the Federal Agency for Tourism, as well as data from various databases of industry enterprises. It is shown that the process of classification of accommodation facilities is necessary for these regions. The following problems of the modern hotel services market in the territories of the analyzed regions are identified: 1) the general passivity of the managers of accommodation facilities in relation to the classification procedure and obtaining a category poses a threat of reducing their number already in 2022 or their transition to the shadow sector of the economy; 2) a small number of accommodation facilities that have received the category of 4 and 5 stars; 3 ) the indicator of saturation of the market with collective accommodation facilities of the regions is lower than the all-Russian one, which indicates an insufficient number of hotels and other accommodation facilities in the regions of the Golden Ring.
\end{abstract}

Keywords: Accommodation facilities, Classification of accommodation facilities, Categorization of hotels, Structure of collective accommodation facilities, Tourism services, Hotel services, Hospitality industry, Central Federal District of the Russian Federation. 


\section{INTRODUCTION}

The hospitality industry is an integral element of the consumer market, one of the most popular objects for investment, as well as an indicator of the development of tourism in the regions [1]. The COVID-19 pandemic has caused a crisis in the service sector [2], and above all in the tourism and hospitality sectors. The consequences of quarantine have had a significant impact on the state and recovery of the tourism industry, making domestic travel destinations more attractive compared to foreign ones. It is necessary to create conditions for the development of tourism by creating opportunities for comfortable and varied recreation within the country, ensuring the functioning of highquality accommodation facilities [3].

Regional markets of hotel services are characterized by their specificity, which can be reflected through the specifics of the placement of hotel facilities, their structure, as well as the demand for services and the results of the activities carried out [4]. The assessment of the development of regional and global markets of hotel services is an actual study and is presented in various works. For example, in [5] the features of the hospitality industry in different regions of the world are revealed, the characteristics of the hotel market of the former Soviet Union are shown, it is concluded that the development of the global hotel industry is acyclic, which is manifested in positive growth rates of key indicators with downward trends in global economic development. The studies [6, 7, and 8] identified the key factors of the development of hotels and other accommodation facilities in various countries of the world (Spain, China, and Russia). The works [9, 10] study the hospitality industry in certain subjects of Russia (Rostov region, Krasnodar Territory).

However, the issues of analyzing the current state and problems of the development of accommodation facilities in relation to individual regions of the Russian Federation are not considered sufficiently and very asymmetrically. This is especially true for the Central Federal District of the Russian Federation. The purpose of the study was to analyze and summarize information about the regional markets of hotel services.

\section{MATERIALS AND METHODS}

The following research tools are used in the article: system analysis; methods of analysis and synthesis, as well as tools of formal logic; methods of comparison

Table 1. Key performance indicators of collective accommodation facilities in 2019 in the context of the subjects of the Russian Federation

\begin{tabular}{|l|c|c|c|c|c|}
\hline \multicolumn{1}{|c|}{$\begin{array}{c}\text { Subject of the Russian } \\
\text { Federation }\end{array}$} & $\begin{array}{c}\text { Number of collective } \\
\text { accommodation } \\
\text { facilities, units }\end{array}$ & $\begin{array}{c}\text { Number of small } \\
\text { accommodation } \\
\text { facilities, units. }\end{array}$ & $\begin{array}{c}\text { The specific } \\
\text { weight of small } \\
\text { accommodation } \\
\text { facilities, \% }\end{array}$ & $\begin{array}{c}\text { Number of } \\
\text { overnight stays, } \\
\text { thousand units }\end{array}$ & $\begin{array}{c}\text { The number of } \\
\text { persons placed, } \\
\text { thousand people. }\end{array}$ \\
\hline Vladimir region & 246 & 94 & 38.2 & 1823.3 & 703.7 \\
\hline Ivanovo region & 111 & 102 & 91.9 & 1318.3 & 263.4 \\
\hline Kostroma region & 108 & 76 & 70.4 & 896.5 & 300.6 \\
\hline Yaroslavl region & 228 & 125 & 54.8 & 2211.4 & 861.4 \\
\hline
\end{tabular}

Table 2. Short cut keys for the template

\begin{tabular}{|c|c|c|c|c|c|c|c|c|}
\hline \multirow[t]{2}{*}{ The name of the indicator } & \multicolumn{2}{|c|}{ Vladimir region } & \multicolumn{2}{|c|}{ Ivanovo region } & \multicolumn{2}{|c|}{ Kostroma region } & \multicolumn{2}{|c|}{ Yaroslavl region } \\
\hline & $\begin{array}{c}\begin{array}{c}\text { Number } \\
\text { of } \\
\text { enterpris } \\
\text { es, units }\end{array} \\
\end{array}$ & $\begin{array}{c}\text { Share, } \\
\%\end{array}$ & $\begin{array}{l}\text { Number of } \\
\text { enterprises, } \\
\text { units }\end{array}$ & $\begin{array}{c}\text { Share, } \\
\%\end{array}$ & $\begin{array}{l}\text { Number of } \\
\text { enterprises, } \\
\text { units }\end{array}$ & Share, \% & $\begin{array}{l}\text { Number of } \\
\text { enterprises, } \\
\text { units }\end{array}$ & $\begin{array}{c}\text { Share, } \\
\%\end{array}$ \\
\hline 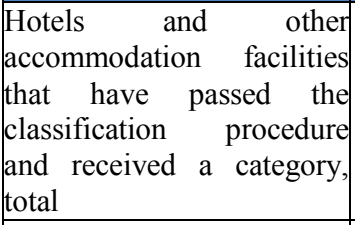 & 115 & 46.7 & 42 & 37.8 & 62 & 57.4 & 148 & 64.9 \\
\hline $\begin{array}{|lr|}\text { including } & \text { small } \\
\text { accommodation } & \text { facilities } \\
(\text { SAF }) & \\
\end{array}$ & 94 & 81.7 & 33 & 78.6 & 49 & 79.0 & 114 & 77.0 \\
\hline 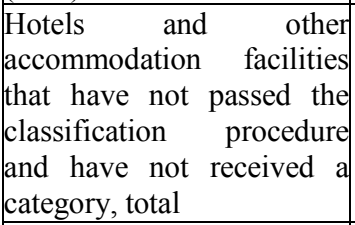 & 131 & 53.3 & 69 & 62.2 & 46 & 42.6 & 80 & 35.1 \\
\hline including SAF & 0 & 0.0 & 69 & 100 & 27 & 58.7 & 11 & 13.8 \\
\hline Total & 246 & 100 & 111 & 100 & 108 & 100 & 228 & 100 \\
\hline
\end{tabular}


and generalization of the experience of foreign and domestic scientists on the subject under study; methods of official statistics; structuring methods based on processing a large volume of factual material.

\section{RESULTS AND DISCUSSION}

The assessment of accommodation facilities in the regions of the Central Federal District of the Russian Federation was carried out. For comparison, the following regions are selected: Ivanovo, Vladimir, Kostroma and Yaroslavl regions of the Central Federal District of Russia. The choice of research objects is determined by the following main factors: 1) location (close location to the capital of the Russian Federation Moscow), 2) belonging to the famous tourist route "Golden Ring of Russia"; 3) the presence of similar historical, natural and cultural conditions for the development of tourism and the hospitality industry in this region. [11]. The necessary data for the assessment of the accommodation facilities of these regions were obtained from various sources [12], [13], [14].

The main performance indicators of collective accommodation facilities in 2019 in the context of the subjects of the Russian Federation are presented in Table 1.

Of the subjects of the Russian Federation presented in Table 1, the largest number of collective accommodation facilities is located in the Vladimir region, followed by the Yaroslavl, Ivanovo and Kostroma regions. The share of small accommodation facilities is the largest in the Ivanovo region, where their share is $91.9 \%$, the smallest in the Vladimir region $38.2 \%$. The number of overnight stays is the largest in the Yaroslavl region, as well as the number of people accommodated.

With regard to accommodation facilities in the Russian Federation as a whole, it should be noted that from January 1, 2022, a ban on the provision of hotel services without a certificate of assignment to a hotel of a certain category established by the Regulation on the Classification of Hotels will come into force [15]. The structure of classification and non-classification objects, i.e. hotels and other accommodation facilities, of the regions of the Central Federal District of the Russian Federation (as of 01.11.2021) are presented in Table 2.

The number of hotels and other accommodation facilities that have been classified and received a category varies from 37.8 (Ivanovo region) to $64.9 \%$ (Yaroslavl region). A total of 367 accommodation facilities, or $53 \%$, have undergone the categorization procedure in 4 regions. Regional governments need to step up the process of assigning a category for accommodation facilities. Otherwise, their number will be significantly reduced in 2022, or part of the placement funds will go to the shadow sector of the economy.

The general passivity of regional accommodation facilities in relation to the classification procedure may be due, in our opinion, to the following reasons:

* low information content about the classification procedure itself;

* the emergence of additional difficulties in the process of functioning (independent initiation of the categorization procedure, preparation of a package of documents, conclusion of a contract for carrying out work on classification);

* the need for additional costs (the classification procedure for objects with fewer than 50 rooms in the service market varies from 20 to 50 thousand rubles);

* the certificate of category assignment is issued for three years, after which the expert assessment and classification procedure must be re-passed, which can also be negatively perceived by owners of small accommodation facilities [16].

We are convinced that the process of classifying accommodation facilities is necessary. Legalization of their activities, protection of tourists from low-quality hotel services, increasing the level of customer confidence in a particular accommodation facility will eventually have a positive impact on the tourist attractiveness of the region. Systematic work of local authorities with small accommodation facilities is

Table 3. Structure of collective accommodation facilities of regions by assigned category (as of 01.11.2021)

\begin{tabular}{|c|c|c|c|c|c|c|c|c|}
\hline \multirow[t]{2}{*}{ Category } & \multicolumn{2}{|c|}{ Vladimir region } & \multicolumn{2}{|c|}{ Ivanovo region } & \multicolumn{2}{|c|}{ Kostroma region } & \multicolumn{2}{|c|}{ Yaroslavl region } \\
\hline & $\begin{array}{c}\text { Number of } \\
\text { enterprises, } \\
\text { units }\end{array}$ & $\begin{array}{c}\text { Share, } \\
\%\end{array}$ & $\begin{array}{c}\text { Number of } \\
\text { enterprises, units }\end{array}$ & $\begin{array}{c}\text { Share, } \\
\%\end{array}$ & $\begin{array}{l}\text { Number of } \\
\text { enterprises, } \\
\text { units }\end{array}$ & Share, $\%$ & $\begin{array}{l}\text { Number of } \\
\text { enterprises, } \\
\text { units }\end{array}$ & $\begin{array}{l}\text { Share, } \\
\%\end{array}$ \\
\hline $5 *$ & 1 & 0.9 & 0 & 0.0 & 0 & 0.0 & 0 & 0.0 \\
\hline $4 *$ & 22 & 19.1 & 5 & 11.9 & 8 & 12.9 & 14 & 9.4 \\
\hline $3 *$ & 37 & 32.2 & 18 & 42.9 & 25 & 40.3 & 61 & 41.2 \\
\hline $2 *$ & 17 & 14.8 & 5 & 11.9 & 8 & 12.9 & 13 & 8.8 \\
\hline $1 *$ & 0 & 0.0 & 3 & 7.1 & 2 & 3.2 & 1 & 0.7 \\
\hline without * & 38 & 33.0 & 11 & 26.2 & 19 & 30.7 & 59 & 39.9 \\
\hline Total & 115 & 100.0 & 42 & 100.0 & 62 & 100.0 & 148 & 100.0 \\
\hline
\end{tabular}


Table 4. Saturation of the market with collective placement facilities in Russia and individual subjects of the Central Federal District (as of 01.11.2021)

\begin{tabular}{|l|c|c|c|c|c|c|}
\hline \multicolumn{1}{|c|}{ The name of the indicator } & $\begin{array}{c}\text { Unit of } \\
\text { measurement }\end{array}$ & Russia & $\begin{array}{c}\text { Vladimir } \\
\text { region }\end{array}$ & $\begin{array}{c}\text { Ivanovo } \\
\text { region }\end{array}$ & $\begin{array}{c}\text { Kostroma } \\
\text { region }\end{array}$ & $\begin{array}{c}\text { Yaroslavl } \\
\text { region }\end{array}$ \\
\hline $\begin{array}{l}\text { Number of collective } \\
\begin{array}{l}\text { accommodation } \\
\text { facilities } \\
\text { per 10,000 inhabitants }\end{array}\end{array} \quad \begin{array}{c}\text { units / } \\
\text { people }\end{array}$ & 1.96 & 1.81 & 1.11 & 1.71 & 1.82 \\
\hline
\end{tabular}

necessary, coordination of their activities; moreover, it is impossible to allow a situation with illegal provision of hotel services [3].

According to the source [12], as of 01.11.2021, the following structure of accommodation facilities by assigned category exists in the regions (Table 3 ).

As follows from Table 3, in the analyzed regions, on average $38.4 \%$ of accommodation facilities have a category of 3 stars, $34.6 \%$ ones without stars, $13.4 \%$ 4 stars, $11.7 \%-2$ stars, $1.6 \%-1$ star and $0.3 \%-5$ stars.

One of the important indicators of the regional market of hotel services development is such an indicator as "saturation of the market with collective

In the Yaroslavl region, the indicator "saturation of the market with collective accommodation facilities" is the closest to the all-Russian indicator.

Accommodation facilities". In the Ivanovo region, the saturation of the market with collective placement facilities is lower than the average in Russia, and also lower than in neighbouring regions of the Central Federal District of Russia (Table 4).

We will analyze the number of rooms of collective accommodation facilities (which have passed categorization), as well as the number of seats in them. The results are presented in table 5 .

In terms of the number of rooms, as well as places in them, the Yaroslavl region is the leader, the smallest number of rooms in accommodation facilities in the Kostroma region, but the smallest number of places in accommodation facilities in the Ivanovo region. In the Ivanovo region, the predominant number of rooms (78\%) in accommodation facilities have the category "First» - this is "a room consisting of 1 living room with one/two beds, with a full bathroom (bath/shower, washbasin, toilet), designed for one/two people" [15]. The rooms of the first category are equipped with a minimum amount of furniture and equipment. Such categories of rooms as "Superior "Suite", "Superior "apartment", "Superior "Suite", "Superior "junior Suite", "Superior "Studio" have a share of less than $10 \%$ in the structure of the room fund of small accommodation facilities of the Ivanovo region - Figure 1.

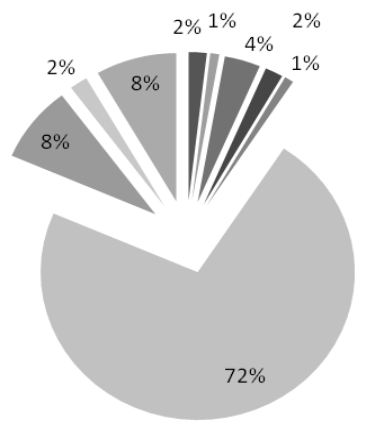

$$
\begin{aligned}
& \text { — higher, "suite" } \\
& \text { — higher "apartment" } \\
& \text { — higher "luxury" } \\
& \text { — higher "junior suite" } \\
& \text { — higher "studio" } \\
& \text { — First } \\
& \text { — Second } \\
& \text { — Fourth } \\
& \text { — Fifth }
\end{aligned}
$$

Figure 1 Structure of the number fund of accommodation facilities of the Ivanovo region, as of $01.11 .2021, \%$.

It follows from the Figure 1 that in the structure of the number fund of accommodation facilities of the Ivanovo region, as of 2020, there is no such category of rooms as the "Third". Thus, most of the accommodation facilities offer rooms of the "First" category with a minimum amount of material and technical base.

\section{CONCLUSION}

The authors investigated the current state and problems of accommodation facilities development. The following problematic areas of development of accommodation facilities were identified:

1) The general passivity of the managers of accommodation facilities in relation to the classification procedure and obtaining a category poses a threat of reducing their number already in 2022 or their transition to the shadow sector of the economy;

2) A small number of accommodation facilities that have received a category of 4 and 5 stars;

3) The indicator of saturation of the market with collective accommodation facilities of the regions is lower than the all-Russian one, which indicates an insufficient number of hotels and other accommodation facilities in the regions of the Golden Ring.

Taking into account the listed problems in the accommodation sector, as well as threats and negative

Table 5. Number of rooms and places in accommodation facilities (categorized) of regions (as of 01.11.2021)

\begin{tabular}{|l|l|c|c|c|c|}
\hline No & Name of the indicator & Vladimir region & Ivanovo region & Kostroma region & Yaroslavl region \\
\hline 1 & Number of rooms in accommodation facilities & 4453 & 2355 & 2249 & 6589 \\
\hline 2 & Number of places in accommodation facilities & 9170 & 4187 & 4515 & 13400 \\
\hline
\end{tabular}


trends in the development of the external environment (in particular, the COVID-19 pandemic and the restrictions associated with it), it is necessary to create conditions in the regions in which enterprises will be able to actively engage in all processes of industry development, the necessary information and consulting environment will be formed, and authorities will be able to carry out operational control over all changes in the accommodation sector.

\section{AUTHORS' CONTRIBUTIONS}

During the writing of the article all authors participated equally during in the collection and processing of information, as well as in the discussion. Professor Astratova also carried out general and scientific editing of the text of the article and its translation into English.

\section{ACKNOWLEDGMENTS}

The authors express their gratitude for the help and support of the employees of Russian hospitality industry companies, who kindly provided advice and information for this publication, but wished to remain incognito.

\section{REFERENCES}

[1] A. P. Vostrova, M. M. Kireeva, Interregional analysis of the hospitality industry (based on the materials of the Ivanovo, Vladimir, Kostroma and Yaroslavl regions), in: Collection of articles of the International Scientific and Practical Conference "Institutional and infrastructural aspects of the development of various economic systems", Tyumen, January 11, 2018. Tyumen: OMEGA SCIENCES Limited Liability Company, pp. 52-60 (2018).

[2] G. V. Astratova, E. B. Bedrina, V. A. Larionova, G. V. Poshekhonova, T. K. Rutkauskas, E. V. Sinitsyn, M. G. Sinyakova, A. V. Tolmachev, Higher education and the labour market in the digital economy: the development of mathematical methods and tools for the study of complex economic systems. Yekaterinburg: UrFU (2021).

[3] S. Y. Tsehla, I. G. Pavlenko, M. M. Kireeva, Improving the efficiency of using the resource potential of small accommodation facilities in the development of tourism (2021).

[4] I. G. Pavlenko, The Russian market of hotel services: the state and prospects of development of international and national hotel chains, in: Service in Russia and abroad, 13, 2 (84), (2019), pp. 44-53.

[5] N. E. Goryushkina,, I. B. Vakhrushev, M. Kh. Akhmetova, E. V. Pesotskaya, N. E. Voinova, The world hotel market: current state and development trends, in: International Journal of Mechanical Engineering and Technology, 9(12), (2018), pp. 618-627.

[6] A. Vives, M. Jacob, Dynamic pricing in different Spanish resort hotels, in: Tourism Economics, 27(2), (2021), pp. 398-411.

[7] S. Zhang, H. Ju, The regional differences and influencing factors of tourism development on Hainan Island, China, PLoS ONE 16 (2021).

[8] A. V. Romanyuk, R. R. Gareev, Hospitality industry in Russia: key problems and solutions, in: Journal of Environmental Management and Tourism, 10(4), (2019), pp. 788-800.

[9] A. Petrenko, G. Ekinil, V. Provotorina, E. Davidova, Development of modern forms of hotel farm in the region, E3S Web of Conferences (2021).

[10] T. Volkova, V. Minenkova, Tourist Complex of the South of Russia in modern conditions, in: 13th International MEDCOAST Congress on Coastal and Marine Sciences, Engineering, Management and Conservation, MEDCOAST, (2017), pp. 327338.

[11] M. M. Kireeva, Comparative assessment of the level and effectiveness of the development of small accommodation facilities in the Ivanovo region, in: Geopolitics and ecogeodynamics of regions, 7, 1, (2021), pp. 109-122.

[12] Federal list of tourist sites. https://xn---7sba3acabbldhv3chawr15bzn.xn--p1ai.

[13] Export Base: database of Russian and CIS companies. https://export-base.ru.

[14] Rosstat Statistical Bulletin for the World Tourism Day 2020. https://rosstat.gov.ru/storage/mediabank/7ZtU1mU D/turizm-2020.docx.

[15] On the extension of permits and other features in relation to licensing activities in 2020 and 2021: Decree of the Government of the Russian Federation of 03.04.2020 No. 440 (ed. of 17.03.2021). ConsultantPlus. http://www.consultant.ru/document/cons_doc_LAW_3 49481/af00ee0e5e6fab4613527e0f070c2700ea48a7eb.

[16] Kommersant. https://www.kommersant.ru/doc/4653573. 